\title{
Effects and significance of formononetin on expression levels of HIF-1 $\alpha$ and VEGF in mouse cervical cancer tissue
}

\author{
YUE ZHANG，CHEN CHEN and JUN ZHANG \\ Department of Gynaecology, Wuxi People's Hospital Affiliated to Nanjing Medical University, \\ Wuxi, Jiangsu 214023, P.R. China
}

Received November 7, 2018; Accepted April 23, 2019

DOI: $10.3892 / \mathrm{ol} .2019 .10567$

\begin{abstract}
Effects and significance of formononetin on the expression levels of hypoxia-inducible factor- $1 \alpha$ (HIF-1 $\alpha)$ and vascular endothelial growth factor (VEGF) in mouse cervical cancer tissue were investigated. The animal models of Balb/c nude mice with cervical cancer were established by the inoculation of HeLa cells, and randomly divided into positive control $(n=10)$, cisplatin $(n=15)$ and formononetin group $(n=15)$. Mice were all sacrificed on the 31st day after administration, and their tumors were excised and weighed to calculate tumor inhibition rate. At the same time, their cancer tissues were obtained. RT-qPCR was used for detecting the mRNA expression levels of HIF-1 $\alpha$ and VEGF, and western blotting for detecting the protein expression levels. During the medication intervention, mice in the formononetin group had no obvious adverse reactions, and were in good condition, whereas mice in the cisplatin group had poor appetite, drooping spirits and decreased activity. Mice in the cisplatin and the formononetin groups had significantly lower tumor mass and volume than those in the positive control group $(\mathrm{P}<0.05)$. The tumor inhibition rate of mice was $56.24 \%$ in the cisplatin group, and $50.17 \%$ in the formononetin group. Cervical cancer mice in the formononetin and the cisplatin groups had significantly lower mRNA and protein expression levels of HIF-1 $\alpha$ and VEGF in tissues than those in the positive control group $(\mathrm{P}<0.05)$. Formononetin can inhibit the growth of cervical cancer and reduce the mRNA and protein expression levels of HIF-1 $\alpha$ and VEGF in mouse cervical cancer. Formononetin has an inhibitory effect on cervical cancer tumors similar to that of cisplatin, but the former has smaller side effects, providing data for the clinical use in cervical cancer.
\end{abstract}

Correspondence to: Dr Yue Zhang, Department of Gynaecology, Wuxi People's Hospital Affiliated to Nanjing Medical University, 299 Qingyang Road, Liangxi, Wuxi, Jiangsu 214023, P.R. China E-mail: rchqse@163.com; 359180072@qq.com

Key words: formononetin, cervical cancer, mouse model, vascular endothelial growth factor, hypoxia-inducible factor- $1 \alpha$

\section{Introduction}

Cervical cancer is a malignant tumor and its incidence is second only to breast cancer. There is a gradual trend for younger age, seriously threatening life and health of females around the world and causing serious economic burden on families and society $(1,2)$. There are 528,000 new patients with cervical cancer worldwide each year with 266,000 deaths, exceeding any other gynecologic tumor $(3,4)$. According to reports in the literature, the mortality of cervical cancer is the eighth in malignant tumors in China. Compared to the 1970 s, the mortality has decreased in the past 10 years, but the incidence in young females has increased. In addition, the mortality is still high in rural areas (5).

Hypoxia-inducible factor-1 $\alpha$ (HIF-1 $\alpha$ ), a subunit of HIF-1 that regulates angiogenesis, and the growth, metastasis and apoptosis of tumors, promotes angiogenesis by regulating vascular endothelial growth factor (VEGF). It also improves oxygen carrying capacity, and maintains cell oxygen stability in hypoxic tissues and tolerance to hypoxia $(6,7)$. The high expression of HIF-1 $\alpha$ regulates cellular energy metabolism and promotes tumor angiogenesis (8). VEGF is by far the most potent pro-angiogenic factor, which is synthesized and secreted by various tumor cells (9). Stimulating the growth of endothelial cells to enhance vascular permeability, it promotes the expression of various cathepsins, which degrades extracellular matrix and promotes tumor angiogenesis $(10,11)$.

At present, advanced cervical cancer is mainly treated by operation, radiotherapy and chemotherapy in clinical practice (12). Patients with stage II B or above are mainly comprehensively treated based on radiotherapy, with a five-year disease-free survival rate of approximately $67 \%$ and greater side effects $(13,14)$. Even if radiotherapy technology and equipment are constantly updated and improved, the growth of primary tumors still cannot be effectively controlled (15). Therefore, it is of great significance to seek targeted drugs for treating cervical cancer. Astragalus membranaceus is a traditional Chinese medicine with invigorating $q i$ and diuretic efficacy, detoxification and myogenic efficacy (16). As a phytoestrogen, one of main components of astragalus membranaceus, formononetin has the effect of regulating estrogen, metabolism, inflammation, and lowering blood pressure (17-19). Currently, studies have shown that it can inhibit bladder cancer and breast cancer $(20,21)$. 
In this study, the effects and significance of formononetin on the expression levels of HIF-1 $\alpha$ and VEGF in mouse cervical cancer tissue were investigated, to provide references for clinical use.

\section{Materials and methods}

Subjects, grouping and modeling. A total of 45 healthy, female, $\mathrm{Balb} / \mathrm{c}$ nude mice were selected, aged 6-8 weeks and weighing 15-20 g. They were purchased from Changzhou Carvins Laboratory Animal Co., Ltd. (Changzhou, China) with an animal certificate number of SCXK (Su) 2011-0003. They were reared in cages at room temperature between 23 and $25^{\circ} \mathrm{C}$ with a humidity of $55-62 \%, 12 / 12$ light cycles, free access to food and drink ad libitum. Modeling experiments were performed after 1 week of adaptive feeding in all mice.

This study was approved by the Ethics Committee of Wuxi People's Hospital Affiliated to Nanjing Medical University (Wuxi, China). Patients who participated in this research had complete clinical data. Signed informed consents were obtained from the patients or the guardians.

Cervical cancer HeLa cells (item no. C015; Nanjing Laifusai Biotechnology Co., Ltd., Nanjing, China) were digested with trypsin (item no. EB04590; Shanghai Shifeng Biotechnology Co., Ltd., Shanghai, China) and prepared into single cell bacterial suspension with a serum-free medium, at a concentration of $1 \times 10^{8} / \mathrm{ml}$. Then, $0.3 \mathrm{ml}$ of HeLa cell suspension was inoculated into the subcutaneous position of the left side of the armpit of the nude mouse near the back, and the tumor growth was recorded. Tumor volume $=$ (longest diameter of the tumor) $\mathrm{x}$ (shortest diameter) ${ }^{2}$ x 0.5 (22). On the 6th day of inoculation, 40 nude mice were tumorigenic. The tumor diameter exceeding $2.0 \mathrm{~mm}$ indicated successful modeling. Among the remaining 5 nude mice, 1 mouse was not tumorigenic, and the remaining 4 mice had tumor diameters $<2.0 \mathrm{~mm}$.

The 40 mice successfully modeled were randomly divided in formononetin group $(n=15)$, cisplatin group $(n=15)$ and positive control group $(n=10)$. Mice in positive control group were administered with $0.1 \mathrm{ml}$ of $0.9 \%$ saline (item no. PB180353; Wuhan Bafeier Biotechnology Service Co., Ltd., Wuhan, China) once a day. Mice in cisplatin group were intraperitoneally administered ( $3 \mathrm{mg} / \mathrm{kg}$ cisplatin dissolved in $0.9 \%$ saline) with $0.1 \mathrm{ml}$ of cisplatin (item no. RB187; Shanghai Guangrui Biotechnology Co., Ltd., Shanghai, China) solution, once every 7 days after modeling. On the other days, $0.1 \mathrm{ml}$ of $0.9 \%$ saline was intraperitoneally injected every day. Mice in formononetin group were intragastrically administered (10 $\mathrm{mg} / \mathrm{kg}$ formononetin dissolved in $0.9 \%$ saline) with $0.1 \mathrm{ml}$ of formononetin (item no. JKM0063; Shanghai Jingke Chemical Technology Co., Ltd., Shanghai, China) solution once a day. The mice were observed during the medication intervention. All the mice were sacrificed on the 31st day after the administration, and their tumors were excised and weighed to calculate the tumor inhibition rate. Tumor inhibition rate $=$ (average tumor weight of mice in positive control group - that in medication intervention groups)/that in positive control group $x 100 \%$. At the same time, their cancer tissues were obtained. The mRNA and protein expression levels of HIF- $1 \alpha$ and VEGF in tissues were detected.
$R T-q P C R$ detection of $m R N A$ expression levels of HIF-1 $\alpha$ and $V E G F$. First $100 \mathrm{mg}$ of cervical cancer tissue was obtained from mice, ground and pulverized, then $1 \mathrm{ml}$ of TRIzol lysate (Shanghai Pufei Biotechnology Co., Ltd., Shanghai, China) was added to isolate total RNA from the tissues. After extraction, $1.5 \%$ agarose gel electrophoresis was used for analyzing RNA integrity, a micronucleic acid determinator (Beijing Meilin Hengtong Instrument Co., Ltd., Beijing, China) for detecting the purity and concentration of the extracted RNA. A260/A280 value was considered to meet experimental requirements between 1.8 and 2.0. Then, $2 \mu \mathrm{g}$ of the total RNA was taken, and a reverse transcription kit (ReverAid TM First Strand cDNA synthesis kit, \#k1622; Promega Corporation, Madison, WI, USA) was used to synthesize cDNA. Reaction system: 5XPrimerScript Buffer $2 \mu \mathrm{l}$, PrimerScript RT enzyme mix $0.5 \mu \mathrm{l}$, Random 6 mers $(100 \mu \mathrm{M}) 0.5 \mu \mathrm{l}$, Oligo dT Primer $(50 \mu \mathrm{M})$ $0.5 \mu \mathrm{l}$, total RNA $2 \mu \mathrm{g}$, dd $\mathrm{H}_{2} \mathrm{O}$ was added to $10 \mu \mathrm{l}$. Reaction conditions: $25^{\circ} \mathrm{C}$ for $5 \mathrm{~min}, 42^{\circ} \mathrm{C}$ for $60 \mathrm{~min}, 70^{\circ} \mathrm{C}$ for $5 \mathrm{~min}$. Products of $2 \mu \mathrm{l}$ was subjected to PCR cycle with SYBR-Green PCCR kit (Beyotime, Shanghai, China), after pre-denaturation at $94^{\circ} \mathrm{C}$ for $3 \mathrm{~min}$, denaturation at $94^{\circ} \mathrm{C}$ for $45 \mathrm{sec}$, renaturation at $58^{\circ} \mathrm{C}$ for $30 \mathrm{sec}$, extension at $72^{\circ} \mathrm{C}$ for $45 \mathrm{sec}$, for a total of 35 cycles, and then extension at $72^{\circ} \mathrm{C}$ for $10 \mathrm{~min}$ after the cycles. $\beta$-actin was used as a reaction internal reference. All the samples were determined 3 times. $2^{-\Delta \mathrm{Cq}}$ was used to calculate the mRNA expression levels of HIF-1 $\alpha$ and VEGF in normal tissues of mice in the control group and in cancer tissues of mice in the formononetin, the cisplatin and the positive control groups (23). Primer sequences are shown in Table I.

Western blotting for the detection of protein expression levels of HIF-1 $\alpha$ and VEGF. Cervical cancer tissue (100 mg) was obtained from mice, ground and pulverized. An appropriate amount of RIPA lysate (item no. EX6010-100 ml; Jinkelong Biotechnology Co., Ltd., Beijing, China) containing $100 \mathrm{mM}$ PMSF was added, and shaken on ice for $30 \mathrm{~min}$ to fully lyse the cells to extract total protein. Then $8 \%$ SDS-PAGE (item no. LM0014A; Shanghai Lianmai Bioengineering Co., Ltd., Shanghai, China) was used for electrophoresis separation. PVDF (item no. 28416245; Suzhou Ruinuode Biotechnology Co., Ltd., Suzhou, China) was left at room temperature for $2 \mathrm{~h}$ after transmembrane. Rabbit anti mice HIF-1 $\alpha$ monoclonal antibody (cat. no. 36169; dil, 1:700) and VEGF primary antibody (cat. no. 2479; dil, 1:1,000) both from Cell Signaling Technology, Inc., (Danvers, MA, USA) were respectively added, shaken for $30 \mathrm{~min}$ and incubated at $4^{\circ} \mathrm{C}$ overnight. After the membrane was washed with TBST (item no. P0233; Beyotime Institute of Biotechnology, Shanghai, China) 3 times, HRP-labeled secondary antibody dilution (cat. no. SA00001-2; dil, 1:2,000; Wuhan Sanying Biotechnology, Wuhan, China) was added, incubated at room temperature for $120 \mathrm{~min}$ and then exposed in the dark. $\beta$-actin (cat. no. 8457; dil, 1:1,000; Cell Signaling Technology, Inc.) was used as an internal reference. A chemiluminescence imaging system (GelView 6000 Pro; Guangzhou Yunxing Scientific Instrument Co., Ltd.) was used for gray-light scanning, and photoshop software for analyzing the relative expression of the protein, repeated 3 times.

Statistical analysis. SPSS17.0 statistical software (SPSS, Inc., Chicago, IL, USA) was used for analysis. Measurement data 
Table I. Primers for HIF- $1 \alpha$ mRNA and VEGF mRNA and internal reference sequences.

\begin{tabular}{lll}
\hline Genes & \multicolumn{1}{c}{ Upstream primers } & \multicolumn{1}{c}{ Downstream primers } \\
\hline HIF-1 $\alpha$ & 5'-TCACGAGGGGTTCCCGCCTCGCA-3' & 5'-TGCGAGGCGGGAAACCCCTCGTGA-3' \\
VEGF & 5'-GGATCCATGAACTTTCTGCT-3' & 5'-GAATCCACCGCCTCGGCTTGTC-3' \\
$\beta$-actin & 5'-CCAGCCTTCCTTCTTGGGTAT-3' & 5'-TTGGCATAGAGGTCTTTACGG-3' \\
\hline
\end{tabular}

HIF-1 $\alpha$, hypoxia-inducible factor-1 $\alpha$; VEGF, vascular endothelial growth factor.

Table II. Inhibition rates of formononetin and cisplatin on cervical cancer.

\begin{tabular}{lcccr}
\hline Groups & $\mathrm{n}$ & Tumor mass $(\mathrm{g})$ & Tumor volume $\left(\mathrm{cm}^{3}\right)$ & Tumor inhibition rate $(\%)$ \\
\hline Positive control & 10 & $8.73 \pm 2.15$ & $10.91 \pm 4.58$ & 0.00 \\
Formononetin & 15 & $4.35 \pm 0.86^{\mathrm{a}}$ & $6.22 \pm 1.61^{\mathrm{a}}$ & 50.17 \\
Cisplatin & 15 & $3.82 \pm 0.73^{\mathrm{a}}$ & $5.76 \pm 1.26^{\mathrm{a}}$ & 56.24 \\
F & & 51.040 & 13.700 & $<0.001$ \\
P-value & & $<0.001$ & & \\
\hline
\end{tabular}

${ }^{\mathrm{a}} \mathrm{P}<0.05$, compared to positive control group.

Table III. Effects of formononetin and cisplatin on mRNA expression levels of HIF-1 $\alpha$ and VEGF in cervical cancer tissue.

\begin{tabular}{lccc}
\hline Groups & $\mathrm{n}$ & HIF-1 $\alpha$ & VEGF \\
\hline Positive control & 10 & $0.79 \pm 0.27$ & $0.53 \pm 0.18$ \\
Formononetin & 15 & $0.46 \pm 0.17^{\mathrm{a}}$ & $0.32 \pm 0.15^{\mathrm{a}}$ \\
Cisplatin & 15 & $0.38 \pm 0.12^{\mathrm{a}}$ & $0.26 \pm 0.10^{\mathrm{a}}$ \\
F & & 15.750 & 11.370 \\
P-value & & $<0.001$ & $<0.001$ \\
\hline
\end{tabular}

${ }^{\mathrm{a}} \mathrm{P}<0.05$, compared to positive control group. HIF-1 $\alpha$, hypoxia-inducible factor- $1 \alpha$; VEGF, vascular endothelial growth factor.

were expressed as mean \pm standard deviation, and tested by the t-test. One-way ANOVA was used for comparison among groups, paired t-test for comparison in the group. $\mathrm{P}<0.05$ was considered to indicate a statistically significant difference.

\section{Results}

Inhibition rates of formononetin and cisplatin on cervical cancer tumors. During the medication intervention, mice in the formononetin group had no obvious adverse reactions, and were in good condition, whereas mice in the cisplatin group had poor appetite, drooping spirits and decreased activity. There were statistically significant differences in the tumor mass and volume of mice among the cisplatin, the formononetin and the positive control groups $(\mathrm{P}<0.001)$. Mice in the cisplatin and the formononetin groups had significantly lower tumor mass and tumor volume than those in the positive control group, with statistically significant differences $(\mathrm{P}<0.05)$, but there was no significant difference in those between the formononetin and the cisplatin groups $(\mathrm{P}>0.05)$.
The tumor inhibition rate of mice was $56.24 \%$ in the cisplatin group, and $50.17 \%$ in the formononetin group (Table II).

Effects of formononetin and cisplatin on mRNA expression levels of HIF-1 $\alpha$ and VEGF in cervical cancer tissue. There were statistically significant differences in the mRNA expression levels of HIF-1 $\alpha$ and VEGF in mouse tissue among the cisplatin, the formononetin and the positive control groups $(\mathrm{P}<0.001)$. Mice with cervical cancer in the formononetin and the cisplatin groups had significantly lower mRNA expression levels of HIF- $1 \alpha$ and VEGF in tissues than those in the positive control group, with statistically significant differences $(\mathrm{P}<0.05)$, but there was no significant difference in those between the formononetin and the cisplatin groups $(\mathrm{P}>0.05$; Fig. 1 and Table III).

Effects of formononetin and cisplatin on protein expression levels of HIF-1 $\alpha$ and VEGF in tissues of cervical cancer. There were statistically significant differences in the protein expression levels of HIF-1 $\alpha$ and VEGF in tissues of mice 
Table IV. Effects of formononetin and cisplatin on protein expression levels of HIF-1 $\alpha$ and VEGF in cervical cancer tissue.

\begin{tabular}{lccc}
\hline Groups & $\mathrm{n}$ & HIF-1 $\alpha$ & VEGF \\
\hline Positive control & 10 & $0.84 \pm 0.19$ & $0.73 \pm 0.16$ \\
Formononetin & 15 & $0.51 \pm 0.14^{\mathrm{a}}$ & $0.36 \pm 0.12^{\mathrm{a}}$ \\
Cisplatin & 15 & $0.41 \pm 0.13^{\mathrm{a}}$ & $0.28 \pm 0.10^{\mathrm{a}}$ \\
F & & 25.630 & 42.330 \\
P-value & & $<0.001$ & $<0.001$
\end{tabular}

${ }^{\mathrm{a}} \mathrm{P}<0.05$, compared to positive control group. HIF-1 $\alpha$, hypoxia-inducible factor- $1 \alpha$; VEGF, vascular endothelial growth factor.

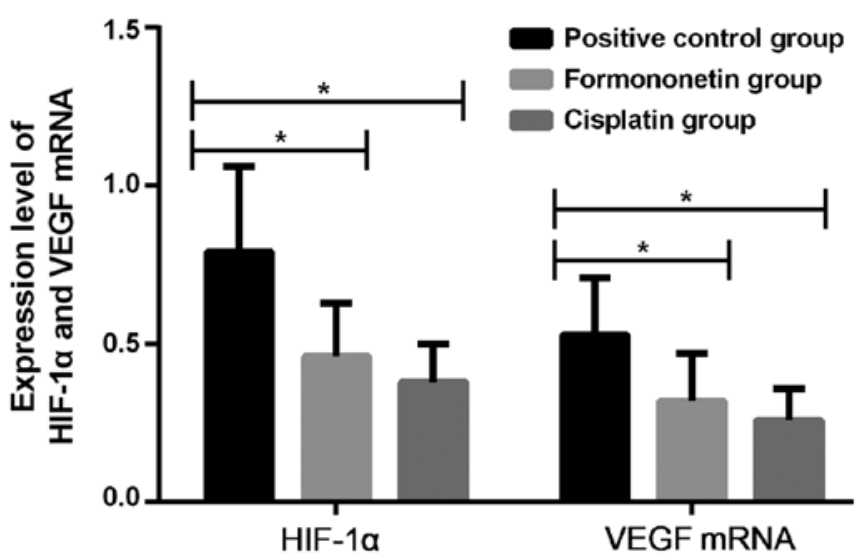

Figure 1. Effects of formononetin and cisplatin on mRNA expression levels of HIF-1 $\alpha$ and VEGF in mouse tissue with cervical cancer. The results of RT-qPCR showed that there were statistically significant differences in the mRNA expression levels of HIF-1 $\alpha$ and VEGF in mouse tissue among the cisplatin, the formononetin and the positive control groups $(\mathrm{P}<0.001)$ Mice with cervical cancer in the formononetin and the cisplatin groups had significantly lower mRNA expression levels of HIF-1 $\alpha$ and VEGF in tissues than those in the positive control group, with statistically significant differences $(\mathrm{P}<0.05)$, but there was no significant difference in those between the formononetin and the cisplatin groups $(\mathrm{P}>0.05)$. $\mathrm{P}<0.05$. HIF-1 $\alpha$, hypoxia-inducible factor-1 $\alpha$; VEGF, vascular endothelial growth factor.

among the cisplatin, the formononetin and the positive control groups $(\mathrm{P}<0.001)$. Mice with cervical cancer in the formononetin and the cisplatin group had significantly lower protein expression levels of HIF-1 $\alpha$ and VEGF in tissues than those in the positive control group, with statistically significant differences $(\mathrm{P}<0.05)$, but there was no significant difference in those between the formononetin and the cisplatin groups (P>0.05; Fig. 2 and Table IV).

\section{Discussion}

Cervical cancer, a common malignant tumor in female, is caused by complex changes in multi-gene and multi-factor interactions (24). Its pathogenesis in tumor angiogenesis is particularly important in the hypoxic condition (25-27). HIF-1 $\alpha$ promotes the proliferation of cancer cells, and VEGF induces the division of vascular endothelial cells to promote tumor growth (28). In addition to killing cancer cells, radiotherapy also causes damage to patients' immune function (29). Chemotherapeutics affect patients' quality of life, with greater toxic and side effects (30). Therefore,

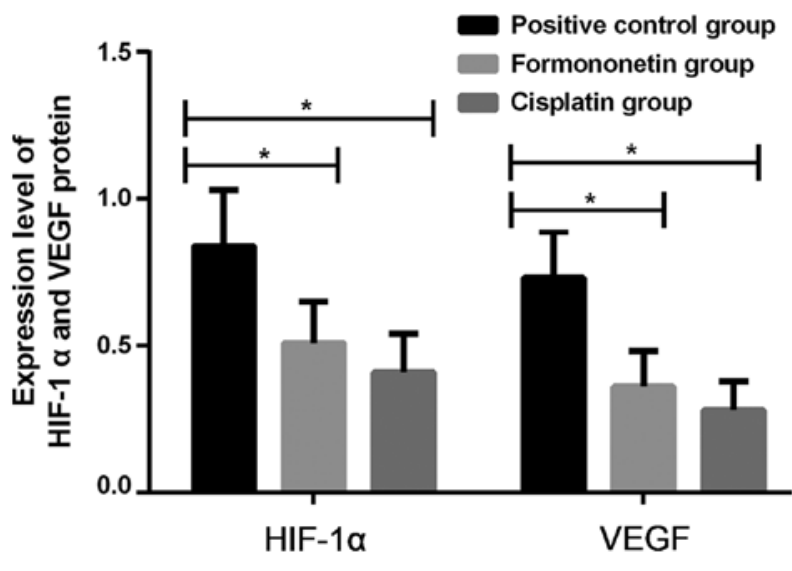

Figure 2. Effects of formononetin and cisplatin on protein expression levels of HIF-1 $\alpha$ and VEGF in mouse tissue with cervical cancer. The results of western blotting showed that there were statistically significant differences in the protein expression levels of HIF-1 $\alpha$ and VEGF in mouse tissue among the cisplatin, the formononetin and the positive control groups $(\mathrm{P}<0.001)$. Cervical cancer mice in the formononetin and the cisplatin groups had significantly lower protein expression levels of HIF- $1 \alpha$ and VEGF in tissues than those in the positive control group, with statistically significant differences $(\mathrm{P}<0.05)$, but there was no significant difference in those between the formononetin and the cisplatin groups $(\mathrm{P}>0.05)$. ${ }^{*} \mathrm{P}<0.05$. HIF- $1 \alpha$, hypoxia-inducible factor-1 $\alpha$; VEGF, vascular endothelial growth factor.

medical workers are increasingly concerned about new bio-targeted therapies. According to reports in the literature, formononetin can inhibit the proliferation of osteosarcoma cell line U2OS (31), colorectal cancer cell line HCT-116, DU-145, HeLa and gastric cancer cell line SGC-7901 (32), as well as promote apoptosis.

This study showed that during the medication intervention, mice in the formononetin group had no obvious adverse reactions, and were in good condition, but mice in the cisplatin group had poor appetite, drooping spirits and decreased activity. Mice in the cisplatin and the formononetin groups had significantly lower tumor mass and tumor volume than those in the positive control group, with statistically significant differences $(\mathrm{P}<0.05)$, but there was no significant difference in those between the formononetin and the cisplatin groups ( $\mathrm{P}>0.05)$. The tumor inhibition rate of mice was $56.24 \%$ in the cisplatin group, and $50.17 \%$ in the formononetin group. Therefore, in this experiment, formononetin had an anti-tumor effect on treating mice with cervical cancer similar to cisplatin, but the former has no significant adverse reactions with more mildly effects. This may be due to the fact that as 
a phytoestrogen with mild nature, small toxic and side effects, and diverse biological activities, formononetin has multiple effects such as anti-tumor, immune regulation, anti-oxidation, lowering blood lipid and cholesterol (33). According to research by Kim et al (34), the high expression of HIF-1 $\alpha$ and VEGF in cervical cancer tissues is correlated with clinical stage, pathological grade and lymph node metastasis. In order to verify the correlation between the inhibition of tumor growth by formononetin and the expression levels of HIF-1 $\alpha$ and VEGF, RT-qPCR and western blotting were performed. The results showed that mice with cervical cancer in the formononetin and the cisplatin group had significantly lower mRNA expression levels of HIF- $1 \alpha$ and VEGF in tissues than those in the positive control group, with statistically significant differences $(\mathrm{P}<0.05)$, but there was no significant difference in those between the formononetin and the cisplatin groups $(\mathrm{P}>0.05)$. Mice with cervical cancer in the formononetin and the cisplatin groups had significantly lower protein expression levels of HIF-1 $\alpha$ and VEGF in tissues than those in the positive control group, with statistically significant differences $(\mathrm{P}<0.05)$, but there was no significant difference in those between the formononetin and the cisplatin groups $(\mathrm{P}>0.05)$. In the study by Bachtiary et al (35), the results of immunohistochemistry show that patients with HIF-1 $\alpha$ expression in cervical cancer tissues account for $72.1 \%$. The HIF- $1 \alpha$ expression occurred in the early stage of tumor formation, and it is speculated that HIF-1 $\alpha$ may play an important role in the occurrence and development of tumors. The study by Birner et al (36) found that patients with high expression of HIF-1 $\alpha$ have significantly lower overall survival time than patients with moderate or no expression of HIF-1 $\alpha$, and the high expression of HIF-1 $\alpha$ is an important prognostic indicator of early cervical cancer. The study by Chen et al (37) shows that the expression of HIF-1 $\alpha$ and VEGF are closely related to tumor angiogenesis, and HIF-1 $\alpha$ may play an important role in the invasion and tumor angiogenesis of gastric cancer. Highly expressed HIF-1 $\alpha$ is closely correlated with tumor recurrence and distant metastasis. The finding of Jin et al (38) are consistent with ours. Their results show that formononetin promotes apoptosis of cervical cancer HeLa cells, and has an anti-tumor effect. Our experiments have confirmed that formononetin can inhibit cervical cancer. It is speculated that it may inhibit cancer by inhibiting the expression levels of HIF-1 $\alpha$ and VEGF. However, the specific mechanism is still unclear, which requires more in-depth research.

In summary, formononetin can inhibit the growth of cervical cancer tumors and reduce the mRNA and protein expression levels of HIF-1 $\alpha$ and VEGF in mouse tissue with cervical cancer. Formononetin has an inhibitory effect on cervical cancer tumors similar to cisplatin, but the former has smaller side effects, and can provide useful data for clinical application.

\section{Acknowledgements}

Not applicable.

\section{Funding}

No funding was received.

\section{Availability of data and materials}

The datasets used and/or analyzed during the current study are available from the corresponding author on reasonable request.

\section{Authors' contributions}

YZ wrote the manuscript. YZ and JZ contributed to PCR and western blotting. CC and JZ were responsible for the model construction. All authors read and approved the final manuscript.

\section{Ethics approval and consent to participate}

This study was approved by the Ethics Committee of Wuxi People's Hospital Affiliated to Nanjing Medical University (Wuxi, China). Patients who participated in this research had complete clinical data. Signed informed consents were obtained from the patients or the guardians.

\section{Patient consent for publication}

Not applicable.

\section{Competing interests}

The authors declare that they have no competing interests.

\section{References}

1. Li X, Zheng R, Li X, Shan H, Wu Q, Wang Y and Chen W: Trends of incidence rate and age at diagnosis for cervical cancer in China, from 2000 to 2014. Chin J Cancer Res 29: 477-486, 2017.

2. Cao S, Liu W, Li F, Zhao W and Qin C: Decreased expression of lncRNA GAS5 predicts a poor prognosis in cervical cancer. Int J Clin Exp Pathol 7: 6776-6783, 2014.

3. Ferlay J, Soerjomataram I, Dikshit R, Eser S, Mathers C, Rebelo M, Parkin DM, Forman D and Bray F: Cancer incidence and mortality worldwide: Sources, methods and major patterns in GLOBOCAN 2012. Int J Cancer 136: E359-E386, 2015.

4. Cancer Genome Atlas Research Network, Albert Einstein College of Medicine, Analytical Biological Services, Barretos Cancer Hospital, Baylor College of Medicine, Beckman Research Institute of City of Hope, Buck Institute for Research on Aging, Canada's Michael Smith Genome Sciences Centre, Harvard Medical School, Helen F. Graham Cancer Center \&Research Institute at Christiana Care Health Services, et al: Integrated genomic and molecular characterization of cervical cancer. Nature 543: 378-384, 2017.

5. WHO Guidelines Approved by the Guidelines Review Committee: Comprehensive cervical cancer control: a guide to essential practice. 2nd edition. World Health Organization, Geneva, 2014.

6. Du PL, Wu KS, Fang JY, Zeng Y, Xu ZX, Tang WR, Xu XL and Lin K: Cervical cancer mortality trends in China, 1991-2013, and predictions for the future. Asian Pac J Cancer Prev 16: 6391-6396, 2015.

7. Wang J, Li G, Wang Y, Tang S, Sun X, Feng X, Li Y, Bao G, Li P, Mao X, et al: Suppression of tumor angiogenesis by metformin treatment via a mechanism linked to targeting of HER2/HIF-1 $\alpha /$ VEGF secretion axis. Oncotarget 6: 44579-44592, 2015.

8. Noman MZ, Desantis G, Janji B, Hasmim M, Karray S, Dessen P, Bronte V and Chouaib S: PD-L1 is a novel direct target of HIF-1 $\alpha$, and its blockade under hypoxia enhanced MDSC-mediated T cell activation. J Exp Med 211: 781-790, 2014.

9. Wigerup C, Påhlman S and Bexell D: Therapeutic targeting of hypoxia and hypoxia-inducible factors in cancer. Pharmacol Ther 164: 152-169, 2016.

10. Jussila L and Alitalo K: Vascular growth factors and lymphangiogenesis. Physiol Rev 82: 673-700, 2002. 
11. Rocha SF, Schiller M, Jing D, Li H, Butz S, Vestweber D, Biljes D, Drexler HC, Nieminen-Kelhä M, Vajkoczy P, et al: Esm1 modulates endothelial tip cell behavior and vascular permeability by enhancing VEGF bioavailability. Circ Res 115: 581-590, 2014.

12. Zhao K, Song X, Huang Y, Yao J, Zhou M, Li Z, You Q, Guo Q and Lu N: Wogonin inhibits LPS-induced tumor angiogenesis via suppressing PI3K/Akt/NF- $\mathrm{KB}$ signaling. Eur J Pharmacol 737: 57-69, 2014

13. Hosaka M, Watari H, Takeda M, Moriwaki M, Hara Y, Todo Y, Ebina Y and Sakuragi N: Treatment of cervical cancer with adjuvant chemotherapy versus adjuvant radiotherapy after radical hysterectomy and systematic lymphadenectomy. J Obstet Gynaecol Res 34: 552-556, 2008.

14. Siva S, Herschtal A, Thomas JM, Bernshaw DM, Gill S, Hicks RJ and Narayan K: Impact of post-therapy positron emission tomography on prognostic stratification and surveillance after chemoradiotherapy for cervical cancer. Cancer 117: 3981-3988, 2011.

15. Lee HJ, Kim YS, Shin SS, Nam JH, Kim YT, Han S and Choi EK: Long-term outcomes of concomitant chemoradiotherapy incorporating high-dose-rate brachytherapy to treat locally advanced cervical cancer. Tumori 98: 615-621, 2012.

16. Casagrande N, De Paoli M, Celegato M, Borghese C, Mongiat M, Colombatti A and Aldinucci D: Preclinical evaluation of a new liposomal formulation of cisplatin, lipoplatin, to treat cisplatin-resistant cervical cancer. Gynecol Oncol 131: 744-752, 2013.

17. Agyemang K, Han L, Liu E, Zhang Y, Wang T and Gao X: Recent advances in astragalus membranaceus anti-diabetic research: pharmacological effects of its phytochemical constituents. Evid Based Complement Alternat Med 2013: 654643, 2013.

18. Sun T, Wang J, Huang LH and Cao YX: Antihypertensive effect of formononetin through regulating the expressions of eNOS, 5 -HT2A/1B receptors and $\alpha 1$-adrenoceptors in spontaneously rat arteries. Eur J Pharmacol 699: 241-249, 2013.

19. Ha H, Lee HY, Lee JH, Jung D, Choi J, Song KY, Jung HJ, Choi JS, Chang SI and Kim C: Formononetin prevents ovariectomy-induced bone loss in rats. Arch Pharm Res 33: 625-632, 2010.

20. Huh JE, Nam DW, Baek YH, Kang JW, Park DS, Choi DY and Lee JD: Formononetin accelerates wound repair by the regulation of early growth response factor-1 transcription factor through the phosphorylation of the ERK and p38 MAPK pathways. Int Immunopharmacol 11: 46-54, 2011.

21. Wu Y, Zhang X, Li Z, Yan H, Qin J and Li T: Formononetin inhibits human bladder cancer cell proliferation and invasiveness via regulation of miR-21 and PTEN. Food Funct 8: 1061-1066, 2017.

22. Zhou R, Xu L, Ye M, Liao M, Du H and Chen H: Formononetin inhibits migration and invasion of MDA-MB-231 and 4T1 breast cancer cells by suppressing MMP-2 and MMP-9 through PI3K/AKT signaling pathways. Horm Metab Res 46: 753-760, 2014.

23. Livak KJ and Schmittgen TD: Analysis of relative gene expression data using real-time quantitative PCR and the 2 [-Delta Delta C(T)] method. Methods 25: 402-408, 2001

24. Lachenmayer A, Toffanin S, Cabellos L, Alsinet C, Hoshida Y, Villanueva A, Minguez B, Tsai HW, Ward SC, Thung S, et al: Combination therapy for hepatocellular carcinoma: additive preclinical efficacy of the HDAC inhibitor panobinostat with sorafenib. J Hepatol 56: 1343-1350, 2012.
25. Waggoner SE: Cervical cancer. Lancet 361: 2217-2225, 2003

26. Mahasiripanth T, Hokputsa S, Niruthisard S, Bhattarakosol P and Patumraj S: Effects of Acanthus ebracteatus Vahl on tumor angiogenesis and on tumor growth in nude mice implanted with cervical cancer. Cancer Manag Res 4: 269-279, 2012.

27. Eckert AW, Lautner MH, Schütze A, Taubert H, Schubert J and Bilkenroth U: Coexpression of hypoxia-inducible factor-1 $\alpha$ and glucose transporter-1 is associated with poor prognosis in oral squamous cell carcinoma patients. Histopathology 58: 1136-1147, 2011.

28. Shi D, Guo W, Chen W, Fu L, Wang J, Tian Y, Xiao X, Kang T, Huang $\mathrm{W}$ and Deng W: Nicotine promotes proliferation of human nasopharyngeal carcinoma cells by regulating $\alpha 7 \mathrm{AChR}, \mathrm{ERK}$, HIF-1 $\alpha$ and VEGF/PEDF signaling. PLoS One 7: e43898, 2012.

29. Chen Y, Liu BL, Shang B, Chen AS, Liu SQ, Sun W, Yin HZ Yin JQ and Su Q: Nutrition support in surgical patients with colorectal cancer. World J Gastroenterol 17: 1779-1786, 2011.

30. Kayl AE and Meyers CA: Side-effects of chemotherapy and quality of life in ovarian and breast cancer patients. Curr Opin Obstet Gynecol 18: 24-28, 2006

31. Hu W and Xiao Z: Formononetin induces apoptosis of human osteosarcoma cell line U2OS by regulating the expression of Bcl-2, Bax and MiR-375 in vitro and in vivo. Cell Physiol Biochem 37: 933-939, 2015.

32. Ren J, Xu HJ, Cheng H, Xin WQ, Chen X and Hu K: Synthesis and antitumor activity of formononetin nitrogen mustard derivatives. Eur J Med Chem 54: 175-187, 2012.

33. Chen J and Sun L: Formononetin-induced apoptosis by activation of Ras/p38 mitogen-activated protein kinase in estrogen receptor-positive human breast cancer cells. Horm Metab Res 44 943-948, 2012.

34. Kim NS, Kang YJ, Jo JO, Kim HY, Oh YR, Kim YO, Jung MH, Ock MS and Cha HJ: Elevated expression of thymosin $\beta 4$, vascular endothelial growth factor (VEGF), and hypoxia inducible factor (HIF)-1 $\alpha$ in early-stage cervical cancers. Pathol Oncol Res 17: 493-502, 2011.

35. Bachtiary B, Schindl M, Pötter R, Dreier B, Knocke TH, Hainfellner JA, Horvat R and Birner P: Overexpression of hypoxia-inducible factor 1alpha indicates diminished response to radiotherapy and unfavorable prognosis in patients receiving radical radiotherapy for cervical cancer. Clin Cancer Res 9: 2234-2240, 2003.

36. Birner P, Schindl M, Obermair A, Plank C, Breitenecker G and Oberhuber G: Overexpression of hypoxia-inducible factor 1alpha is a marker for an unfavorable prognosis in early-stage invasive cervical cancer. Cancer Res 60: 4693-4696, 2000.

37. Chen WT, Huang CJ, Wu MT, Yang SF, Su YC and Chai CY: Hypoxia-inducible factor-1alpha is associated with risk of aggressive behavior and tumor angiogenesis in gastrointestinal stromal tumor. Jpn J Clin Oncol 35: 207-213, 2005.

38. Jin YM, Xu TM, Zhao YH, Wang YC and Cui MH: In vitro and in vivo anti-cancer activity of formononetin on human cervical cancer cell line HeLa. Tumour Biol 35: 2279-2284, 2014.

This work is licensed under a Creative Commons Attribution-NonCommercial-NoDerivatives 4.0 International (CC BY-NC-ND 4.0) License. 